Instructions for authors, subscriptions and further details:

\title{
http://rimcis.hipatiapress.com
}

\section{From the Homestead to Centerstage: A Journey of Empowerment}

Anithamol Babu ${ }^{1}$, Sonny Jose ${ }^{2}$

1) Christ (Deemed to be University), Bangalore, India

2) Loyola College of Social Sciences, Trivandrum, India

Date of publication: article first published online August 8, 2020; Issue published August 30, 2020

Edition period: November 2020 - March 2021

To cite this article: Anithamol Babu and Sonny Jose (2020). From the Homestead to Centerstage: A Journey of Empowerment. International and Multidisciplinary Journal of Social Sciences, 9(3), 230-259 doi:10.17583/rimcis.2020.4401

To link this article: http://doi.org/10.17583/rimcis.2020.4401

\section{PLEASE SCROLL DOWN FOR ARTICLE}

The terms and conditions of use are related to the Open Journal System and to Creative Commons Attribution License (CC-BY). 


\section{From the Homestead to Centerstage: A Journey of Empowerment}

Anithamol Babu

Christ (Deemed to be University)
Sonny Jose

Loyola College of Social Sciences

\section{Abstract}

The Kerala Model of Development has been widely acclaimed for its contribution in generating favourable social indices at par with Scandinavia. The central issue to the development in almost all underdeveloped and developing countries is the empowerment of women constituents. In Kerala, the story of empowerment of women is not just economic, but psychological too. Under Article 243(D) of the Constitution of India, there is a mandate to provide 50\% reservation for women in Local SelfGovernment Institutions (LSGIs). This constitutional amendment is regarded as a path-breaking move to empower women at the grassroots level. This article portrays the impact of government interventions for ensuring the participation of women in decision-making as well as in the power structure in LSGIs. The researcher(s) used multiple case study design and adopted purposive sampling. The data was collected through in-depth interviews and focus group discussions were used for triangulation. The finding of the study shows that how the women are empowered though various government interventions such as Kudumbashree (the name of Kerala's Poverty Eradication Mission), Mahatma Gandhi National Rural Employment Guarantee Act (the job guarantee scheme in India), Accredited Social Health Activist Scheme (a scheme of National Rural Health Mission) and Local Self-Government Institutions.

Keywords: Women Empowerment, Gender Equality, Government Interventions, Political Participation. 


\section{De La Granja Al Centro De Escena: Un Viaje De Empoderamiento}

Anithamol Babu

Christ (Deemed to be University)
Sonny Jose

Loyola College of Social Sciences

\section{Resumen}

El Modelo de Desarrollo de Kerala ha sido ampliamente aclamado por su contribución en la generación de índices sociales favorables a la par con Escandinavia. La cuestión central para el desarrollo en casi todos los países subdesarrollados y en desarrollo es el empoderamiento de las mujeres constituyentes. En Kerala, la historia del empoderamiento de las mujeres no es solo económica, sino también psicológica. De conformidad con el artículo 243 (D) de la Constitución de la India, existe el mandato de proporcionar una reserva del 50\% para las mujeres en las instituciones locales de autogobierno (LSGI). Esta enmienda constitucional se considera un movimiento innovador para empoderar a las mujeres a nivel de base. Este artículo retrata el impacto de las intervenciones gubernamentales para garantizar la participación de las mujeres en la toma de decisiones, así como en la estructura de poder en los LSGI. El (los) investigador (es) utilizaron un diseño de estudio de caso múltiple y adoptó un muestreo intencional. Los datos se recopilaron a través de entrevistas en profundidad y se utilizaron discusiones de grupos focales para la triangulación. El hallazgo del estudio muestra que la forma en que las mujeres están empoderadas a través de diversas intervenciones gubernamentales como Kudumbashree (el nombre de la Misión de Erradicación de la Pobreza de Kerala), la Ley Nacional de Garantía de Empleo Rural de Mahatma Gandhi (el esquema de garantía de empleo en la India), el Esquema de Activista de Salud Social Acreditado (un esquema de la Misión Nacional de Salud Rural) y las instituciones locales de autogobierno.

Palabras clave: Empoderamiento de la mujer, igualdad de género, intervenciones gubernamentales, participación política

2020 Hipatia Press

ISSN: 2014-3680

DOI: $10.17583 /$ rimcis.2020.4401 


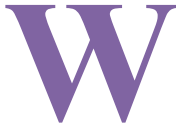

omen constitute around half of the population of any country. However their involvement in politics is insignificant compared to men. A democratic country like India cannot progress much, unless women participate in work, and still further in governance. The word "empowerment" has been given by UN agencies during recent years (Thakur \& Kumara, 2008). In simple words, empowerment is devolving power to others. Power implies having the capacity, as well as the means to direct one's life toward desired social, political and economic goals or status (International Encyclopedia, 1999).

Empowerment of the women implies ensuring equal status to women; the balance of power between women and men is equal and neither party has dominance over the other. The discrimination against women is deeply rooted in the structure of society; it forcibly confines women primarily to the domestic sphere of life (Babu \& Jose, 2019). Gender equality and empowerment of women is recognized globally as a key element to achieve progress in all areas. The political power entails that women have the capability to analyze, organize and mobilize the surrounding situations for social transformation. Political status of women indicates amount of freedom and equality adored by women in sharing power in politics (Palanithurai, 2003). Active political participation and equality cannot be separated. Active political participation beyond the right to vote, involves women in decision making, sharing power, and participation at policy making level providing opportunity for advancement of women and a society. Women's equal status in every sphere is inextricably linked to country's progress and development (Singh, 2004).

To ensure that women get a fair share of public goods and equal participation, India, in 1993, passed the $73^{\text {rd }}$ Amendment by the Parliament, an important step towards 'inclusive' democracy. The $73^{\text {rd }}$ amendment aimed at providing better political space to the vulnerable sections of the society such as Schedule Castes, Schedule Tribes and women at the grass root level, by reserving one-third of the seats all over the country (Kaur, 2000). In other words, the $73^{\text {rd }}$ Amendment mandated women's reservation. This was indeed a crucial step considering the inferior status of women in India, and their consequent 
low participation in public life. The $73^{\text {rd }}$ amendment has brought many women into Local Self-Government Institutions (Raabe et al., 2009).

Later, through Article 243D of the constitution, the Government of India approved the proposal for enhancing reservation of women in Local Self-Government Institutions from the erstwhile one-third to $50 \%$. Women political leaders considered the new reservation policy as a path- breaking decision to help the women to enter public sphere and make the Local Self-Government Institutions more inclusive and improve the public service delivery (Kumar, 2016). This article narrates the experiences of Kerala women encountered after being selected as the representatives of the Local Self-Government Institution as an impact of the Article 243D of the Indian Constitution.

\section{Statement Of The Problem}

Kerala one of the southern-most and progressive states in India has experimented with various forms of progressive social reforms. Historically, in Kerala, the transition from the matriarchal system of family to patriarchal system put in place social structures that bestowed men with the privilege to rule over women. The preconceived notion that the women have to take care of her husband, kids and household chores conditioned women to find comfort in their own homes. In addition, there were negative trends existing in Kerala - absence of women's property rights, transacting dowry as a precondition for marriage, covering the breast, rising gender-based violence, etc. Kerala one of the states in India, long-since acknowledged the need to treat women as 'under-privileged', when compared to men (Babu \& Jose, 2019). Hence, various social reforms introduced during the twentieth century, played an important role in eradicating such evil practices (Das, 2000). Political empowerment of women was necessary because women, who work at home and outside the home, become knowledgeable about challenges at home and outside (Azmi, 2000).

The state, Kerala in South India has been recognized in international level for specific development, known as the 'Kerala model' and equated with Scandinavian countries (Tornquist, 2000; Parayil, 2000; Lindwall \& Bergquist, 2006). As in 2018, the Human Development 
Index Report 2018 rates Kerala at 0.785 , against the all India average of 0.647. Kerala is the state in India with the most favorable gender ratio that is 999 women to 1000 men. The state is free from conventional restrictions against women's education, employment or owning property (Government of India, 2011). Therefore, women empowerment and the participation of women in politics and other power structure were one of the concerns of the Government (Jafar, 2013); it envisaged improvement in totality of all human capabilities role in decision-making, access to information and resources for taking proper decision, and their ability to assert in collective decisionmaking. Besides, women empowerment as a concept must affirm positive thinking on the ability to make changes, ability to learn skills and increasing one's positive self-image (Véron, 2001). Discussions regarding women empowerment and equal participation of women in politics, as now enshrined in SDG Goal 5 of the of United Nations Organization have been on-going with successive governments in Kerala over the years.

The inclusion of Article 243D of the Indian Constitution assured $50 \%$ reservation for women in all Local Self-Government Institutions ensured the participation of women in the power structure. Kumar (2016) assessed that women's participation in politics will lead to women empowerment. In addition, the Government has many interventions to promote useful insights on social and political freedom of women (Fox \& Schumann, 1999). This article examines the outcome of such innovations by attempting to profile women involved in Local Self-Government Institutions (LSGIs), understand the challenges they encounter while engaging LSGIs, as well as the transformation as a result of their engagement.

\section{Literature Review}

Women, most of times are deprived of their fundamental human rights, and this often happens in the context of tradition or traditional practices. On social and economic fronts, women are discriminated throughout their life, from the conception to death. In addition to subordination to male authority as a vestige of the Manusmrithi, they suffer from other 
evils such as female foeticide, differential treatment, malnutrition, child marriage, child labour, dowry deaths, and invisibility as well as nonremuneration of their work. There is also discrimination in administration, sciences, industry and military services. The root cause of all this is illiteracy or apparent lack of education as compared to their male counter parts besides patriarchy (Narayana, 2007). Indeed, in the journey from ancient to modern times, women's position in the society has been assaulted; sometimes she is placed on a high pedestal in myths from where she is portrayed capable of dictating terms; at other times as in contemporary narratives found in soap operas and serials, she is cast as a victim to be tread on and tortured to live in lowliness and misery (Agarwal, 2001).

Globally, the condition of women has not been good in the past. It was the United Nations (U.N.), which has provided the lead to bring women's plight in focus throughout the world. It was perhaps subsequent that development programmes and projects for women were started and given much importance. Such initiatives have come a long way since the U.N. declared 1975, as 'International Women's Year'. In spite of so many initiatives for women, women have still not benefited with all the benefits being monopolized by men, further widening the gender gap in considering economic status. The period 1975-1985 was declared as the 'International Women's Decade'. The Mexico World Conference (1975) declared that: "...problems of women, who constitute half the world population, are problems of the society. The various conventions - "World Summit for Children" (1990), "International Conference on Nutrition" (Rome, 1992), "World Conference on Human Rights" (1993), "International Conference on Population and Development" (1994), "Fourth World Conference on Women" (Beijing, 1995) have emphasised on bringing about structural changes that are necessary in the society, in order to empower women. Scholars, International agencies and Governments have emphasized on the need to ensure women's full and equal participation in the power structures; the term which has come to be in vogue is 'empowerment of women', the kind of empowerment that encompasses other dimensions - social, political and economical. Currently, the Agenda 2030 of U.N. 
addresses gender equality, especially equal participation of women in politics.

The Government of India's Report 'Towards Equality' (1974), was the first major attempt to review and evaluate data on women's role, rights and opportunities in the wake of planned development. This report cites that a majority of women are 'very far from enjoying rights and opportunities' guaranteed by the Constitution. It stressed on the need for political participation and representation of women in political institutions. The Government of India report (1988), 'National Perspective Plan for Women 1988-2000', made significant recommendations regarding representation of women in Local SelfGovernment Institutions. The $73^{\text {rd }}$ Constitutional Amendment in 1993, provided for 33 per cent reservation for women, is considered as the first achievement of Indian Women's Movement (Mayambika, 2003). This landmark amendment focused on political structures and processes of rural India and vulnerable populations.

Earlier, participation of women in LSGIs was questioned in terms of the substance and effectiveness of representation. Local committees insufficiently represented women. Women were rarely heads of LSGIs and hence, needed the entry-level positions to familiarise and advance within the system. Thus, the act has been passed to assure women's representation in LSGIs. Kodoth \& Mishra (2011) found the same has substantially increased the representation of women in local Governments.

The Women's Reservation Bill (108 ${ }^{\text {th }}$ Amendment) in 2008, was a lapsed bill in the Parliament of India, which proposed to amend 33\% of all seats in the Lower House of Parliament of India as well as in all state legislative assemblies, for women. And in 2009, through Article 243D, the Government of India mandated 50 per cent reservation to women in all Local Self-Government Institutions.

It is well accepted that the reservation of women in LSGIs played an important role for the women representation in grassroots politics in India. Women representatives never come to acquire positions in LSGIs, if the reservation is not provided to them (Centre for Women's Development Studies, 1999). Beyond bringing the rural womenfolk in India into the political forum, it has positioned them to influence 
decision making, prepare and implement schemes for economic development and social justice.

The impediments to women's entry into public life were identified by Young (1999). He further argued that, the women's entry and productive role in governance are constrained by number of factors like lack of gender sensitivity of those concerned, poor access to basic social services like education, unfriendly legal structures, and absence of mechanisms which can ensure women's active participation in developmental and political processes for development and which can facilitate community support to assurance of the rights of women and children. According to Young the initiation and entry of women into political and legal structures are expected to transform the process and institutions of governance. The researchers identified that there are no other studies which explored the how Government interventions helped the women to enter into politics and those literatures about LSGIs are before the implementation of 50 per cent reservation for women.

\section{Research Questions}

1. What are the demographic characteristics of women representative in the Local Self-Government Institutions?

2. What are the factors that motivated the women to engage in election to Local Self-Government Institutions?

3. What were the challenges encountered as a representative in the Local Self-Government Institutions, vis-à-vis being women?

4. What were the changes they experienced as result of engaging with Local Self-Government Institutions?

\section{Methodology}

For the study purpose the researchers adopted a qualitative research approach. In order to gets a global understanding about women engaging with Local Self-Government Institutions, the researchers adopted a multiple case study design and selected six women headed Local Self-Government Institutions in Thrissur and Idukki district based on expert opinions. The study pursued purposive sampling in 
identifying participants. The unit of consisted of a woman representative from a ward (a Local Self-Government Institution contains a minimum of 13 wards). Data was collected by way of indepth interviews from 24 subjects, from three different Local SelfGovernment Institutions. Some of them were members of the Kudambashree, workers of Accredited Social Health Activist Scheme under the National Rural Health Mission, while the rest were erstwhile housewives. The primary data generated from the 24 samples was interpreted using content analysis, accompanied with different themes, and represented using graphs and diagrams. The analysis also contains the verbatim from the interviews which can substantiate the results on each objective.

\section{Ethical Considerations}

Permission from the President and the Secretary of the LSGIs are taken for conducting the study. Voluntary consent for participation in the study was taken from the participants before each interview by agreeing the following conditions of the researchers; 1) I will not be directly benefited from the study, 2) I have the right to withdraw from the study(during the study), 3) I understand that the researchers will not reveal my identity, 4) I understand that the researchers will record the interview for research purpose and 5) I understand that the study is for academic and research purpose only.

\section{Results and Discussion}

\section{Demographic Characteristics Of Women LSGI Representatives}

Twenty-four women representatives from 6 women headed Local SelfGovernment Institutions from Thrissur and Iddukki districts of Kerala are covered for the study. 


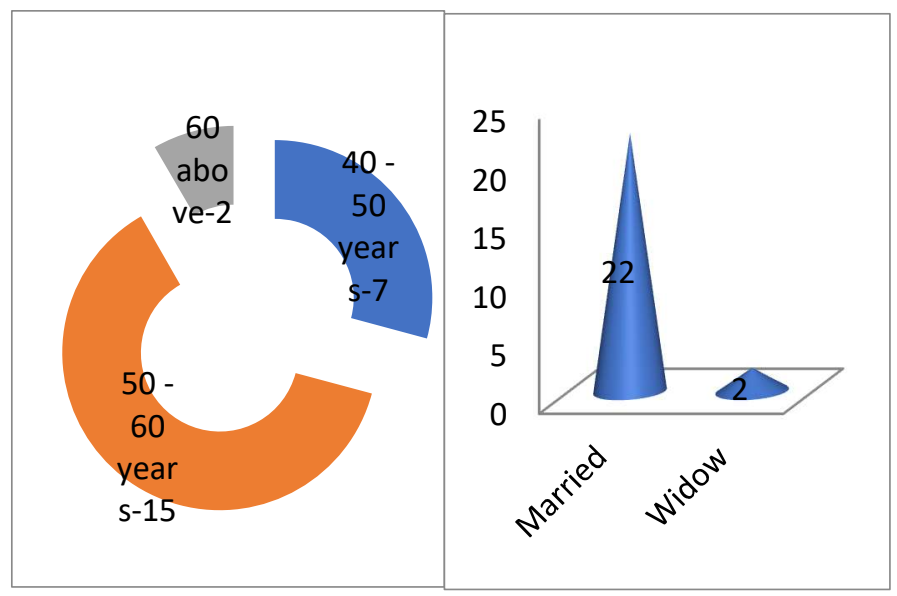

Figure.1 \& 2. Doughnut diagram indicating age-wise distribution of women elected as PRI members and Cone diagram indicating the marital status of women prior to being elected as representatives of Local Self-Government Institutions

More than half of the subjects were in the age-group of 50 to 60 years, and a quarter of participants are between the ages 40 and 50 years; only 2 participants were above 60years of age: "I am 58 years old. My husband passed away five years ago due to cancer and we don't have any children. But my sister's daughter used to live me and my husband. We always considered her as our child" (Case 4).

Twenty-two participants are married and living with their spouses while two are widows. Studies by Tremblay and Kumtakar (1998), Kumari (2000) Bhatt and Kataria (2002), and Singh (2004) indicated that the majority of the women engaging with Local Self-Government Institutions are married. It was also noticed that the majority of the women elected into the LSGIs were into middle adulthood (ages 40 to 65 years), a stage categorised by Erikson as 'generatively vs. stagnation', wherein contribution to the society is common and expected. Generatively refers to "making your mark" on the world through creating or nurturing things that will outlast an individual (Erikson, 1964). 


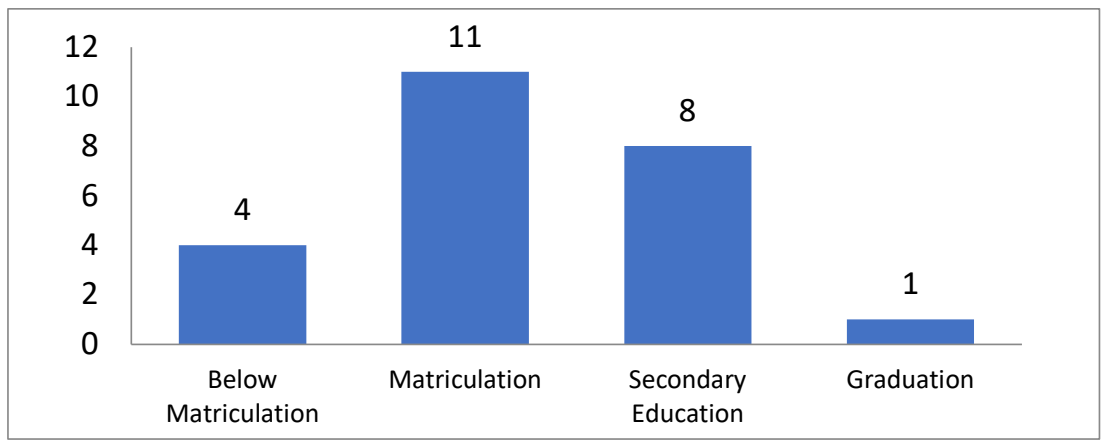

Figure 3. Bar Diagram showing the educational qualifications of the women Local Self-Government representatives

More than three quarters of the participants have matriculation (SSLC), secondary education or degree as their educational qualification; only four have educational qualifications below Matriculation (SSLC): "I'm a degree (Sociology) drop out from the University of Kerala (distance). I stopped as it was the time when the construction of our house was taking place. So, I could not continue" (Case 8).

The present study draws similarities to the study of Buch (2000), wherein most of the women elected into LSGIs were literate.

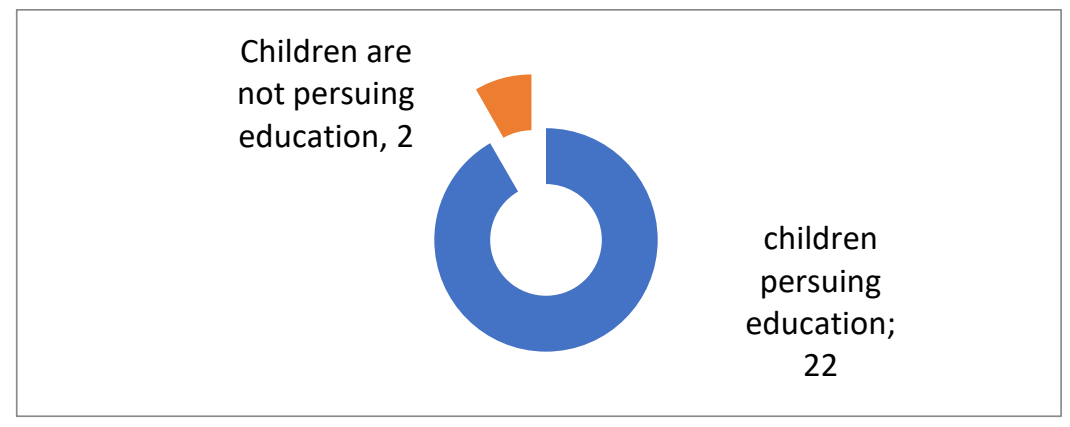

Figure 4. Doughnut Diagram depicting educational details of children of women elected representatives 
Except for two, all the participants had children pursuing school or college education. Poornima and Vyasulu (1999) found that most of the families of the women engaging with LSGIs are nuclear families, which correlates with the current study. Women generally engaged with LSGIs only after they were sure that their kids are independent (Bhaskar, 1997).

\begin{abstract}
My elder child is a college student; she is independent and he does many of the household works with the help of my husband. She also takes care the younger ones. So, I don't have to look after the younger one studying in UP school all the time...in that way I'm blessed. (Case 11)
\end{abstract}

Majority of the participants are giving the first priority to their children and family. This shows women are not keen about their dreams; their primary preoccupation happened to be their husband and family. It is possible to say that the cultural practices and structures propagated by the patriarchal society is the reason for injecting selflimiting thoughts in women (Thanokodi \& Sugirtha, 2007): "At the time I entered into politics it wasn't appropriate for a Muslim woman to come out and stand side by side with men" (Case 18).

Before contesting the elections, fourteen out of twenty-four where the actively involved - in government sponsored projects such as Kudumbashree (8 subjects), the thozhilurappu scheme (pay of work program; MGNREGA) (2 subjects), and as ASHAs (2 subjects) in the NRHM. The remaining 12 were women took the bold, informed decision to venture out of their households, into the mainstream of public life in the Local Self-Government Institutions: “...I was a typical housewife, who engaged exclusively in household...” (Case 20).

After marriage, I was alone at home while my husband was away. It was during that time my neighbour invited me to join the Kudumbashree. A year later both of us started a food-processing for making 'unniyappam' (a sweet snack). It was rewarding and I continued on the same for 6 months until I conceived my kid (Case 11) 


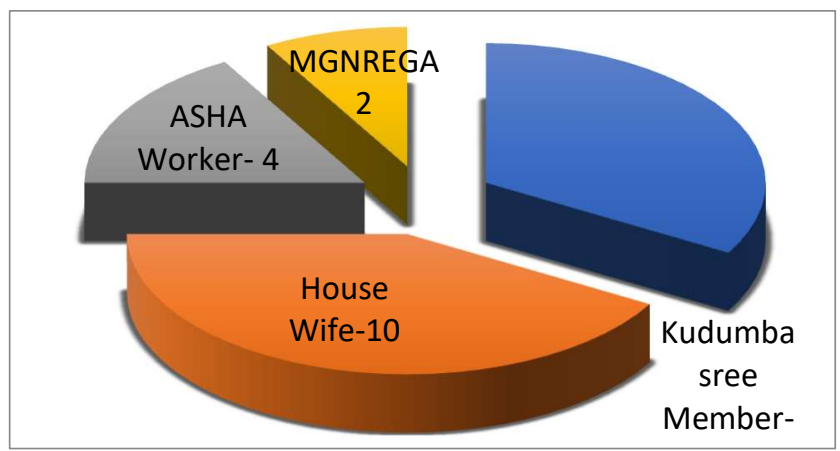

Figure 5. Pie diagram depicting occupational status of women elected as representatives of Local Self-Government Institutions

This result echoes findings by Lindwall \& Bergquist (2006) and Oommen (2008) wherein Government interventions for women empowerment as the development strategies operate as drivers for women coming to the forefront through the interventions used: "My engagement in MGNREGA helped me to earn adequate money besides improving my social interactions. That is perhaps why the party leaders approached me as a probable candidate for the next election" (Case 13).

The engagement with Government interventions helped the women to socialize with the society. It also shows the interest of the participants to be engaged in something, where they could put to good use their skills, and earn money (Anand, 2002). The researchers observed that the housewives were so happy while explaining about their entry to politics and the participants who engaged with Government interventions considered the invitations to political party as the reward of their services and acceptance among the public. 
International and Multidisciplinary Journal of Social Sciences, 9(3) 243

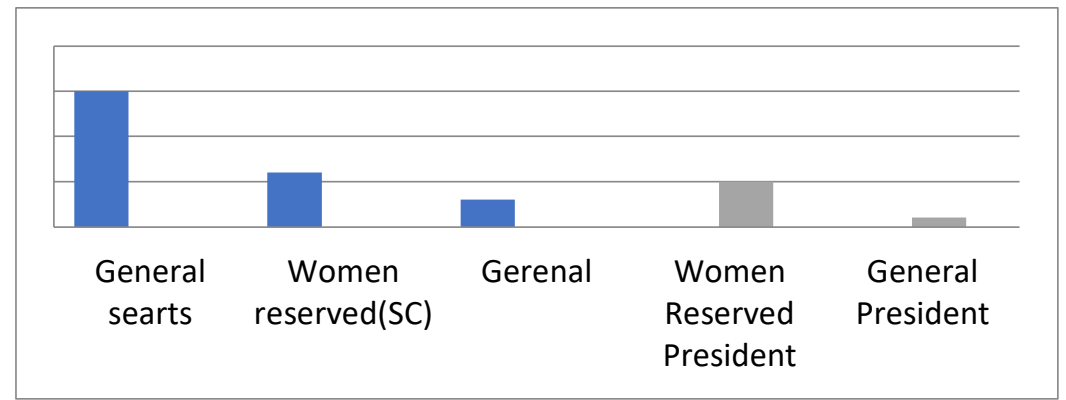

Figure 6. Bar Diagram showing the distribution of women based on the various reservations of seats.

Twenty-one participants availed the 'quota' for women reservation in the General Category or Schedule Caste reservation; only three competed in general seats. Among the twenty-four participants, six occupy the chair of President. Manikyamba (1989), Bhargava and Vidya (1992), found that upper caste women engaged more in politics and willingly entered Local Self-Government Institutions. Women had difficulties winning and occupying seats in Local Self-Government Institutions under the general category (Bhargava and Vidya, 1992). Only one succeeded in becoming a President in the General Category. All this clearly indicates that reservation for women is the sole reason for the women's entry to Local Self-Governments Institutions Besides, it is also understood during the qualitative studies that the consent for contesting elections had to be taken first taken from the husbands.

Our ward was reserved for SC women; the party leaders approached my husband seeking his permission to nominate me as their candidate... he asked about my opinion regarding the proposition, and I replied that I was ready if he consented... (Case 17)

The last part of the woman's explanation perhaps belies the fact as to whether the entire exercise was a party driven or a male-stilted. 


\section{Push Factors That Motivated The Women To Engage In Politics}

More than half of the participants are of the opinion that the political parties to which either they or their spouses belonged to, were the impetus for them to engage and contest the election to Local SelfGovernment Institutions as probable candidates. While eight among the remaining cited Kudumbashree involvement, one subject claimed to be 'self-motivated': "It was my self-determination to take part in the election as an independent candidate because my party leaders did not give me a chance to be nominated as candidate..." (Case 15).

We have a shop in the City, where I used to assist my husband during rush-hours or while he was away... this offered me enormous opportunity to interact with many people. This is perhaps why the party leaders choose me as their candidate. (Case 1)

Only one among the subjects studied cited the request from her husband to contest Local Self-Government elections. And in the case of a lone participant, her husband asked her to participate in election.

My husband is a politician. He asked me to contest the elections since our ward was reserved for women. Besides he was confident because the particular seat had been held by the party for the past 15 years. (Case 22)

These results are congruent with previous studies by Chandrasekhar and Inbanathan (1991), Verma (1997) and Buch (2000); They found that the party politics was a driving force for involvement of women in politics. Panda (1999) noted of other drivers such as persuasion by family members, the village community, and rarely personal interest as a driving force. 


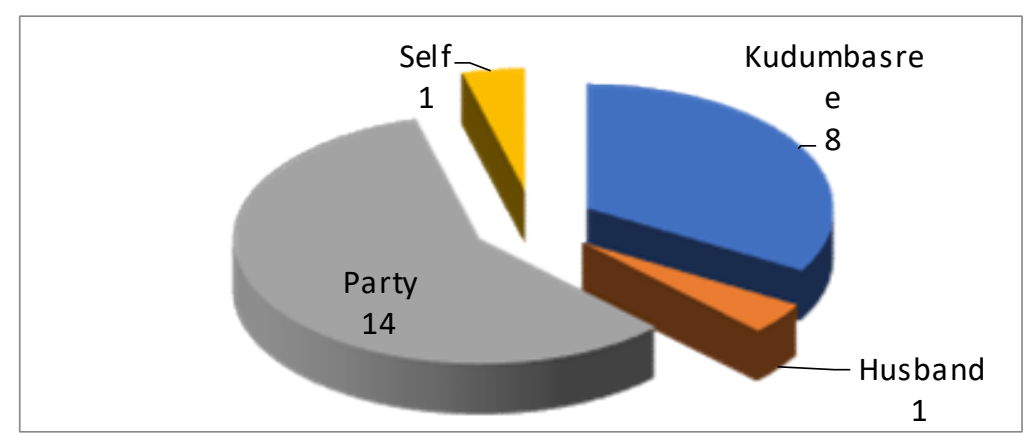

Figure 7. Bar diagram showing the push factor that impels the women Local Self-Government representatives to participate in the election.

\section{Challenges Encountered By Women Representatives}

A quarter of the participants revealed that they did encounter major challenges as the women representatives in the Local Self-Government Institutions.

The challenges include the domains - social, administrative and financial. These challenges restrict the fulfilment of their respective roles taken up as elected representatives. The rest claimed they are facing lack of sufficient knowledge and health challenges.

To an extent I am able to solve their problems but sometimes there will be delay due to other works or procedures related to it. So then there will be time lag. Then others is some of the people who work may sometimes do the work slowly. It will affect the implementation or getting of the services. (Case 1) 


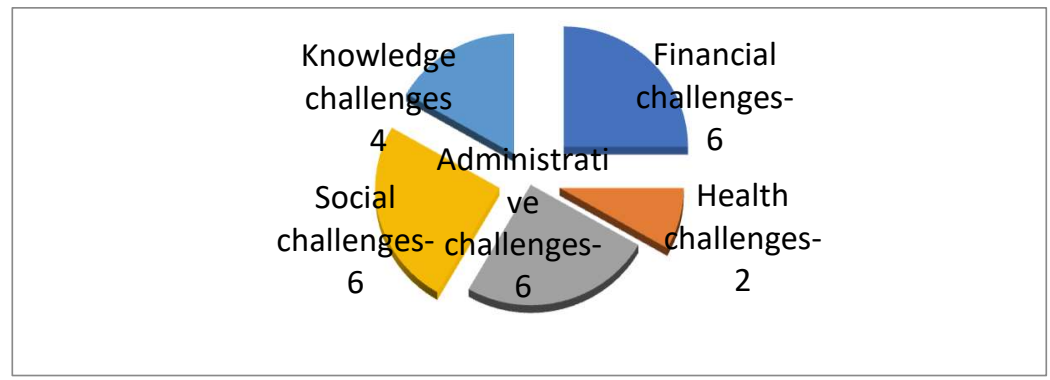

Figure 8. Pie Chart depicting the challenges faced by the women representatives.

Fox \& Schuhrman (1999) found that women have the desire to help people. Kumari (2000) reveals that women faced 'knowledge and engagement' challenges in the Local Self-Government Institutions. Mishra (1998) reported that women representatives of different categories reported that they were not 'treated at par' either by the members of the institutions or by the officials. Poornima and Vyasulu (1999) claims that 'low level of knowledge', 'lack of interest', 'inadequacy of training' appeared to be the causes of a low level of awareness about the Local Self-Government. Shah and Jacob (1995), RamaDevi (2000) cited that women have lots of socio-political challenges such as discriminations from male dominated society, gender discrimination etc. The present study seems to agree with the above mentioned limitations: "The challenge differs between women and men. For a woman, she should manage the household chores, family and the work; but for a man, he they need only manage their work" (Case 17).

O'Donoghue \& Rabin (2000) noted that women across the globe face many difficult challenges and struggles pertaining to inequality, which can take many 'different forms'. Thanikodi \& Sugirtha (2007) found that everywhere in the world women face obstacles to their participation in politics. These barriers are to be found in prevailing social and economic regimes, as well as in existing political structures. 
Particularly for women, the public career of a person depends a great deal on their family background.

The mentality of the people and the society is the major challenge which the women face..If I'm late to come home, my husband or children do not ask why I'm late. That makes me feel responsible and important. However, my neighbours too enquiring as to why I'm late, where I was, who was with me, will I be late tomorrow, etc. made me feel that they were concerned and looked up to me and my work" (Case 2)

Palanithurai (2002) cites the negative attitude of the society towards women; rumour mills roll and character assassination happen if a woman reached home late "...the rumours spread by the opposite party are a big challenge for women...." (Case 3 ).

Challenges were not limited and varied with experience. Some of the other citations are: "Our Local Self-Government Institution has not much 'funds'...it is the major challenge we are facing because we have many plans in the pipeline but cannot implement due to the shortage of funds" (Case 18); "This is a hilly area, so most of the office staff coming here are applying for transfer; their houses may be in the South or North of Kerala and it is difficult for them to go home weekly" (Case 12); "I lack experience and knowledge; I'm a housewife and it is the first time that I'm elected as the representative. I need to learn a lot" (Case 16); "In my perception, getting acceptance from the side of male colleagues is the major challenge which women face in the Local Self-Government Institution as well as in the society" (Case 8).

More than a quarter of the participants (8) had to wake up before 5 am while the rest (16) wake up in between 5am and $7 \mathrm{am}$. Except eight, all participants (16) went to bed before midnight. Almost two quarter of the participants claimed that they will get more than 8 hours sleep per day, while 10 participants get 6-8 hours of sleep. Only and two participants get less than 6 hours sleep. Most among the women LSGI members felt to be supported by family members with their domestic chores (Premajam, 2000). The following are excerpts from the interviews: "My son reaches home after his tuition at11.30 pm....so I 
sleep only after midnight ...I wake up at 4.30 am to prepare breakfast and lunch....after I was elected, my husband also helps me with work in the kitchen" (Case 7).

Majority of the women are not compromising their role as the housewives/mother even though they are selected as the representatives of their family.

I wrote late into the night, the Kudumbashree minutes as while as compile the daily work report of the activities I need to engage with as an ASHA... So I go to bed late at night and wake up early to prepare tiffin for my husband (Case 24).

In Kerala, cooking and child-care are considered major duties of married women even if she works. It is evident from the narration, how social conditioning affects minds of the women; in other words, they are being equated to a domestic without salary (Gupta, 2008): "In my perception, taking care of husband and children is the major challenge which the women...so I decided to contest the election only after I felt, they can be managed ..." (Case 4).

There is apparent disregard for self-care among women, since women are giving more priority to her kids and husband than her (Anand, 2002). The below given illustrations depicts definite change among the men; they help their wives in domestic chores after they get elected as the LSGI representatives.

In fact, my husband asked me to contest the election and promised that he would manage the rest; he does most of the household works even if I'm at home. He says that I need to focus on my responsibilities as the President of the Local Self-Government Institution. Nevertheless, I wake up at 5.30 am; but my husband wakes up much earlier than me. (Case 9)

\section{Changes Experienced As The Result Of Engaging With Politics}

The participants claimed to have experienced a sea of change in their lives as well as in the approach of society towards them after being elected representatives to their respective wards. 


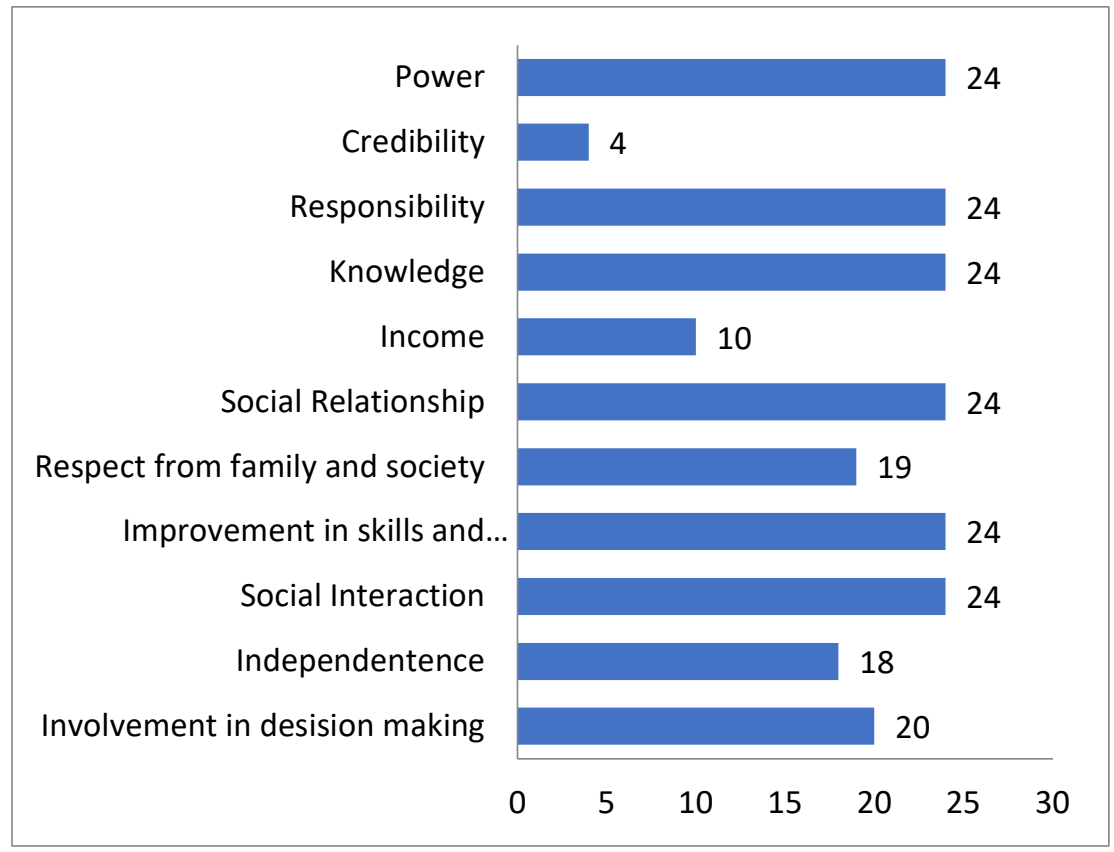

Figure 9. Bar chart depicting the 'changes' experienced by the women respondents who officiated as Local Self-Government Institutions representatives.

All the participants felt that their 'responsibility', 'knowledge-level', 'feeling of powerfulness', 'levels of social relationships' as well as extent of 'social interactions' have increased. They also claimed that their 'skills' and 'capacities' had developed 'substantially'.

I think my knowledge and capacities have improved; three years ago, I did not know the formalities for paying tax, current bill, etc. or how to apply for income certificate, caste certificate, etc. I used to look after my kids and husband and engage in agricultural work on our land; everything else, was looked after by my husband. Now I know where to go, whom to meet, what to speak, etc. My social interactions and social relationships have improved a lot. At present, if I have a legal doubt, I talk to an advocate; similarly, if I have 
medical issues, I enquire with the Medical Officer in PHC, etc. (Case 15)

All the subjects claimed that the public recognition and acceptance helped the participants to appreciate their skills and abilities by themselves. This helped them to contribute better in decision-making at home and at work in the Local Self-Government Institutions. This was significant consider the shift in attitude from patriarchy because earlier women were not part of decision-making process. In general there is better visibility and appreciating coming out of it: "For me the major change is that my family members seek my opinion regarding every major decision concerning their lives..." (Case 17).

I can feel the power as the President of the Local Self-Government Institution...wherever I go, people recognize me ... my children feel proud of me because I'm invited as Chief Guest to almost all programmes organised at their school. My children are known as 'the President's kids'. I heard them say “...three years ago the people recognized us after our Papa. But now, we are recognized as Mama's kids". In retrospect, I feel proud and experience a sense of accomplishment on completing each project ... I understand it is not my lone effort; my colleagues and office staff are also help me in accomplishing each the tasks...we are like one family. It is our joint efforts that helped me to win the Best President Award in our district. My party leaders appreciate me for managing the opposition without much problem. I believe that it is because of the grace of God (Case 4).

I'm more independent now... I learned driving and bought a scooter; so if I am called to solve a problem late in the evening or if I'm late after a meeting at Local Self-Government Institution, I can manage to get home on my own vehicle.... (Case 21)

Being an ASHA worker, I was not interested in contesting the elections. So, during the previous election I did not participate as a candidate and I regret. An ASHA worker can understand the needs of the vulnerable and marginalized provided water-beds to all the patients needing palliative care support in the Local Self- 
Government Institution...many among the women in my ward had expressed their gratitude (Case 13).

Ten participants opined that the 'honorarium' they are paid for their services was a source of substantial 'personal income' for them. Twenty participants are of the opinion that there is a definite progression in their involvement in 'decision-making'. Nineteen participants felt that they earned 'respect' from their family members as well as the society. Four participants claimed that their 'credibility' in the society has increased substantially. Eighteen participants claimed to have increased level of 'autonomy'.

...even though it is a limited honorarium, to me it is like an income that I earn. As a matter of principle, I spend the entire money on the Local Self-Government Institution itself, especially in meeting the needs of the needy (Case 23).

I believe that it is because of the $73^{\text {rd }}$ amendment only that the women are coming into the forefront in the politics or else the status of the women may not change. Reservation is having an important role in empowering women in a positive manner. Now many of the women are independent they are able to make their own decisions. It is only because of the amendment that women are able to come to the forefront. Because of the amendments there are improvements in the case of women as now they can participate along with men and sometimes I do feel like they do better than men.... according to me it is a good initiative brought by the government. Because of the amendment only women are able to come forward and participate along with men. If this amendment wasn't brought now also women may belong to their houses and none will ever come to politics or have a chance to come (Case 17).

Melcher et al. (1992) claimed that the numbers of women engaging with PRIs are increasing. Kodoth \& Mishra (2011) and Ghosh (1997) stated that women started to break the traditions by capitalising on the opportunities avail for them.

We live in the forest. In our 'ooru (community)' women are not allowed to talk to men other than family members. In fact, we are 
not even permitted inside our own residences during menstruation. I'm glad I was able to challenge and bring about changes to these primitive customs to great extent. We have taught our people how to use modern toilets; I would like to view these changes as part of the acceptance and respect they have for me. It feels very empowering that women and men approach me for clarifications, to solve family issues, and settle boundary disputes, etc. even though it is not directly incidental to my role as a Local Self-Govenment representative (Case 7).

I am happy with the reservation for the women, because of that they are able to come forefront and do their best and I feel like women have more empathy than men which makes the women to help others more (Case 8).

Rama Devi (2000), Shaul (1982), Melcher et al. (1992), Bhaskar (1997) and Manikyamba (2003) cite an upper-hand for women in dealing empathetically to others. The authors unanimously agree that women are more sensitive towards the needs of the society and they will put their maximum efforts to solve the issues and problems (Radha \& Chowdhury, 2002).

The drinking water and the road were the major needs in my ward. It was my promise to my people during the election, and I delivered the same within a year. Now I increasingly understand that my credibility and responsibilities have increased; people approach me to solve their problems .and I try to be more conscious about the words I'm using. I have learnt to refuse the demands very politely if I can't do them (Case 13).

The researchers cite the added advantage of a cap on corruption, with women controlling the financial and administrative affairs of the LSGIs, since their intention is to contribute to society rather than making money. 


\section{Conclusion and Gaps For Future Research}

Women are venturing into local politics, and their participation in the decision making and governance of development programmes and schemes is gradually increasing (Kumar, 2016; Radha \& Chowdhury, 2002). However, they face problems and challenges in performance of their responsibilities and roles. Their problems are manifold (Gupta, 2008; Palanithurai, 2002). They experience low self-esteem, lack of confidence, negative stereotyping as 'illiterate', role conflicts at various levels - family, society and governments, compounding social barriers, male-dominance in decision-making, lack of knowledge, educational backwardness, etc. termed to restrict their participation in LSGIs (Rama Devi 2000; Manikyamba, 2003). On the contrary women play a subordinate role in society in most parts of the world. The problem in women's development is the rectification of the lopsided power relations between men and women in society. Men dominate both at home and at work. In local bodies where women have a legal status of power, men tend to exclude them or disregard their view or worse still, physically assault them (Radha \& Chowdhury, 2002).

The Article $243 \mathrm{D}$ of the Indian Constitution may be considered as a historic and path-breaking decision made by the Government of India. It was solely directed at empowering women to take part in decisionmaking process and provide gender equality in entering the power structure at the grassroots challenging the existing social structures. This can be also viewed as an effort taken by a women-headed nation to ensure the participation of women in power structure as the symbol of empowerment. It is found that the Government Interventions such as Kudumbashree, MGNREGA works, as well as ASHA's under the NRHM are also motivating and directing the women to enter mainstream society. Although this study is an exploratory attempt to assess the impact of Article 243D of the Constitution and document experiences of women representatives in Thrissur and Iddukki districts, there is much could be done to document the impact in terms of nature and divisions of Local Self-Government Institutions. The study may be attended to these limitations and recruit a larger sample for a future analysis. 


\section{Notes}

1. Local Self-Government Institutions (LSGIs). Local Self-government is the management and governance of local affairs by a local body or authority. These local bodies may be municipal corporations or Panchayats.

2. Kudumbashree, The State Poverty Eradication Mission (SPEM), popularly known as Kudumbashree Mission is the State government's arm for poverty eradication under the Local Self-Government Department. In the beginning it was an action research from one of the eminent social work in Kerala were the authors studied their M.S.W. degree.

3. Accredited Social Health Activist (ASHA). Accredited Social Health Activist (ASHA) is a trained female community health activist or the link workers under National Rural Health Mission (NRHM), Government of India. Selected from the community itself and accountable to it, the ASHA will be trained to work as an interface between the community and the public health system.

4. Mahatma Gandhi National Rural Employment Guarantee Act (MGNREGA). The Mahatma Gandhi National Rural Employment Guarantee Act (MGNREGA), also known as Mahatma Gandhi National Rural Employment Guarantee Scheme (MNREGS) is Indian legislation enacted on August 25, 2005. The MGNREGA provides a legal guarantee for one hundred days of employment in every financial year to adult members of any rural household willing to do public work-related unskilled manual work at the statutory minimum wage.

5. Secondary School Leaving Certificate (SSLC). The Secondary School Leaving Certificate is a certification obtained by a student on successful completion of an examination at the end of study at the secondary schooling level in India. It is equivalent to Matriculation.

\section{References}

Agarwal, B. (1992). The gender and environment debate: Lessons from India. Feminist studies, 18(1), 119-58.

https://doi.org/10.2307/3178217

Anand, J. S. (2002). Self-Help Groups in Empowering Women: Case study of selected SHGs and NHGs. Kerala Research Programme on Local Level Development. Centre for Development Studies. http://www.cds.ac.in/krpcds/w38.pdf

Azmi, S. (2000). Women as organized agents for poverty eradication, Women and Political Empowerment. In Bidyut Mohanty (Ed.), Women and Political Empowerment (pp. 38-530). Institute of Social Sciences. 
Babu, A., \& Jose, S. (2019). The Media-Ceiling: Are There Women in Media. In S. Pillai (Ed.), The Media World: Gender Perspective (pp. 53-65). Cyber Tech Publications.

Bhargava, B. S., \& Vidya, K. C. (1992). Position of women in political institutions (with to panchayati raj system in

Karnataka). Journal of Rural Development, 2(5), 601-628.

https://agris.fao.org/agris-

search/search.do?recordID=US201301767116

Bhaskar, M. (1997). Women Panchayat Members in Kerala: A Profile.

Economic and Political Weekly, 32(17), WS13-WS20.

https://www.epw.in/journal/1997/17/review-womens-studies-

review-issues-specials/women-panchayat-members-kerala-

profile

Bhatt, G. \& Kataria, S. K. (2002). Mahila Sarpanches: On the move. Journal Social Welfare, 49, 24-28.

Buch, N. (2000). Panchayts and women. In G. Mathew (Ed), The

Status of Panchayati Raj in the States and Union Territories of India (34-41). Concept Publishing Company.

Centre for Women's Development Studies (1999).

https://www.cwds.ac.in/

Chandrasekhar, B., \& Inbanathan, A. (1991). Profile and Participation of women Zilla Parishad and Mandal Panchayat Members: The case of Karnataka. Journal of Rural Development, 17(4), 575589.

Das, S. (2002). Panchayati Raj: women Panchayat Members Fight Against Rigid Value. Grassroots Feature Network: Reporting Human Condition, 3(9), 3-12.

Erikson, E. H. (1964). Insight and Responsibility: Lectures on the Ethical Implications of Psychoanalytic Insight. Norton.

Fox, L. R., \& Schuhmann, R. A. (1999). Gender and Local Government: A Comparison of Women and Men City Managers. Public Administrative Review, 59(3), 231-242. https://doi.org/10.2307/3109951

Ghosh, D. K. (1997). Grassroot Women Leaders: Who are they? A study in a West-Bengal District. Journal Rural Development, 16(2), 291-311. 
Government of India (2011). Census of India - Office of the Registrar General, \& Census Com- missioner, Government of India. http://censusindia.gov.in/2011-Common/CensusData2011.html Gupta, V. S. (2008). Capacity building for effective empowerment of women. Kurukshetra, 50(8), 47-62.

International Encyclopedia of the First World War (1999). https://encyclopedia.1914-1918-online.net/home.html

Jafar, K. (2013). Reservation and Women's Political Freedom:

Candidates' Experience from Three Gram Panchayats in Kerala, India. Social Change, 43(1), 79-97.

https://doi.org/10.1177/0049085713475728

Kaur, G. (2000). Working and interaction style analysis of elected women in the Panchayati Raj system towards empowerment. Ph.D. dissertation (Thesis). Punjab Agricultural University. http://krishikosh.egranth.ac.in/handle/1/5810015708

Kodoth, P., \& Mishra, U. S. (2011). Gender equality in Local Governance in Kerala. Economic and Political Weekly, 46(38), 36-43. https://www.epw.in/journal/2011/38/insight/genderequality-local-governance-kerala.html

Kumar, V. (2016). Impact of Panchayati Raj institutions in women empowerment in Bihar. International Journal of Interventional Research and Advanced Studies, 3(10), 74- 77.

Kumari, R. (2000). Participation of Women in Panchayats :

Challenges of Emerging Leadership. In B. Mohanty (Ed.), Women and Political Empowerment. Institute of Social Sciences.

Kundu, A. (2008). Pros and Cons of Micro Credit Programme. In D. Lazar, \& P. Palanichamy (Eds.), Microfinance and Poverty Eradication (pp. 326-342). New Century Publications. http://www.newcenturypublications.com/servlet/ncpGetBiblio?b no $=000167$

Lindwall, E., \& Bergquist, P. (2006). Women - The Way Out of Poverty - Locating women empowerment in a case study of Kudumbashree. Lund University. https://lup.lub.lu.se/studentpapers/search/publication/1329853 
Manikyamba P. (2003). The numbers dilemma: success stories and manipulative mechanisms. South Asian Journal of sociopolitical studies, 3(2), 12-18.

Manikyamba, P. (1989). Women in Panchayati Raj Structure. Gyan publishing house.

Melcher, D., Elchedt, L. J. \& Eriksen, S. (1992). Women's participation in local union leadership: The Massachusetts Experience. ILR review, 45(2), 267-280. https://doi.org/10.1177/001979399204500205

Mishra, R. (1998). Devotion of power to women. In Panchayati Raj in Orissa: challenges and opportunities. Kurukshetra 47, 19-24. Narayana, D. (2007). Participation of the poor and excluded in local governance: The Indian decentralisation experience. Institutions and Markets in India's Development: Essays for K.N. Raj. Oxford University Press.

O'Donoghue, T., \& Rabin, M. (2000), The economics of immediate gratification. Journal of Behavioral Decision Making, 13(2), 233-250. https://doi.org/10.1002/(SICI)1099-

0771(200004/06)13:2<233::AID-BDM325>3.0.CO;2-U

Oommen, M. A. (2008). Microfinance and poverty alleviation: the Case of Kerala's Kudumbashree. Centre for Socio-economic \& Environmental Studies (CSES).

http://www.kudumbashree.org/storage//files/fqvd6_micro\%20fi nance $\% 20$ and $\% 20$ poverty $\% 20$ alleviation.pdf

Palanithurai, G. (2002). Impediments to the empowerment of women: experiences of elected women representatives in Panchayats in Tamil Nadu. The Indian Journal of Political Science, 63(1), 3749. https://www.jstor.org/stable/42743573

Palanithurai, G. (2003). New Panchayati Raj in Tamilnadu. Concept Publishing Company.

http://www.conceptpub.com/servlet/Detail?bookno=00000797

Panda, S. (1999). Political Empowerment of Women: Case of Orissa

Panchayati Raj Institution. Indian Journal of Public Administration, 45(1), 86-94.

https://doi.org/10.1177/0019556119990109 
Parayil, G. (2000). Kerala - The Development Experience: Reflections on Sustainability and Replicability. Zed Books.

Poornima, V., \& Vyasulu, V. (1999). Women in Panchayati Raj:

Grassroots Democracy in India: Experience from Malgudi.

Economic and Political Weekly, 34(52), 25-31.

https://www.jstor.org/stable/4408775?seq=1

Premajam, A. K. (2000). Women in decision-makers. In H.

Saraswathi (Eds.), Women and Political Empowerment. Institute of Social Sciences.

Raabe, K., Sekher M., \& Birner, R. (2009). The effects of political reservations for women on local governance and rural service provision. International Food Policy Research Institute (IFPRI).

Radha, S., \& Chowdhury, B. R. (2002). Women in Local Bodies.

Kerala Research Programme on Local-level Development, Centre for Development Studies.

http://www.cds.ac.in/krpcds/w40.pdf

Rama, D. (1998). Towards the 73rd and 74th Amendents:

Implications for Women. Women and Political Empowerment.

Institute of Social Sciences.

Shah, A., \& Jacob, S. (1995). Attitudes towards reservation for women. Social Welfare, 11, 72-75.

Shaul, S., \& Marine, S. (1982). The Status of Women in Local

Governments: An International Assessment. Public

Administration Review, 42(6), 491-500.

https://www.jstor.org/stable/976118

Singh, S. (2004). Empowerment of Women Representatives in

Panchayati Raj. Kurukshetra, 52(10), 130-139.

Thakur, A. K., \& Kumara, D. (2008). Gender Empowerment and

Development. Indian Economic Association. Deep \& Deep

Publications.

Thanikodi, A., \& Sugirtha, M. (2007). Status of women in Politics.

The Indian Journal of Political Science, 68(3), 589-606.

https://www.jstor.org/stable/41856357

Törnquist, O. (2000). Dynamics of Indonesian Democratisation. Third World, 21(3), 383-423.

https://doi.org/10.1080/01436590050057708 
International and Multidisciplinary Journal of Social Sciences, 9(3) 259

Tremblay, R. C., \& Kumtakar, P. (1998). Governance and Representation: A Study of Women and Local SelfGovernment. Indian Journal of Public Administration, 17(3), 454-67. https://doi.org/10.1177/0019556119980321

Verma, P. S. (1997). Panchayati-Raj in Punjab: Problems and Prospects. Social Action, 97, 58-72.

Véron, R. (2001). The "new" Kerala Model; Lessons for sustainable development. World Development, 29(4), 601-617. https://doi.org/10.1016/S0305-750X(00)00119-4

Young, I. M. (1999). Justice, inclusion, and deliberative democracy. Deliberative Politics: Essays on Democracy and Disagreement. Oxford University Press. https://philpapers.org/rec/YOUJIA

Anithamol Babu is M.Phil. Scholar at the Christ (Deemed to be University), Bangalore, India

Sonny Jose is professor at the Loyola College of Social Sciences, Trivandrum, India

Contact Address: anithamolbabu@yahoo.in 